DOI https://doi.org/10.18551/rjoas.2018-06.33

\title{
EFFECT OF STOCK PRICE, DEBT TO EQUITY RATIO, RETURN ON ASSET, EARNING PER SHARE, PRICE EARNING RATIO AND FIRM SIZE ON INCOME SMOOTHING IN INDONESIA MANUFACTURING INDUSTRY
}

\author{
Suparningsih Budhi, Tari Dhistianti Mei Rahmawan*, Utomo Fajar Cahyo \\ University of Krisnadwipayana, Indonesia \\ *E-mail: dhistianti@unkris.ac.id
}

\begin{abstract}
The study was conducted to observe the income smoothing on the manufacturing company listed on the Indonesian Stock Exchange. Income smoothing is capable to mislead investors in analyzing financial statements and mislead creditors in long-term loan decision making. The research object is manufacturing industry group, basic industry and chemical sector, cement sub-sector listed on BEI since 2005 - 2017. The research result exhibits that factors influencing the partial earnings are par value stock, debt to equity ratio, earnings per share and price earnings ratio. On the other hand, return on asset and firm size is not significant. All variables studied influences income smoothing.
\end{abstract}

\section{KEY WORDS}

Stock price, debt to equity ratio, return on asset, earning per share, price earning ratio, firm size, income smoothing.

The high economic growth of a country can reflect the greater role of the capital market. The important role of the capital market in the economy is as a means of business financing and as a means for people to invest. According to Sunariyah (2011: 4) the capital market, in general, is an organized financial system, including commercial banks and all financial intermediaries, as well as all circulating securities. United Nations Industrial Development Organization (UNIDO, 2012) research stated that global manufacturing industry in the third quarter of 2012 only grew by 0.2 percent compared to the previous year. The world's manufacturing industry is experiencing severe challenges due to recession in European countries and weakening economic growth in North America, East Asia and slowing economic growth in some developing countries. This global recession will be a constraint to the development. The impact of this slowdown in world economic growth will be a serious problem as it will affect Indonesia's export-oriented manufacturing industry.

Table 1 - GDP Growth per First Quarter Sector 2017

\begin{tabular}{|c|c|c|c|c|c|c|c|c|}
\hline Sectors & 2011 & 2012 & 2013 & 2014 & 2015 & 2016 & $2017^{*}$ & $\begin{array}{l}\text { Share } \\
2016\end{array}$ \\
\hline Manufacturing industry & 6,26 & 5,62 & 4,37 & 4,64 & 4,33 & 4,29 & 4,21 & 20,51 \\
\hline Agriculture, forestry, \& fishery & 3,96 & 4,59 & 4,20 & 4,24 & 3,77 & 3,25 & 7,12 & 13,45 \\
\hline Wholesale \& retail trade, cars \& motorcycles reparations & 9,66 & 5,40 & 4,81 & 5,18 & 2,59 & 3,93 & 4,77 & 13,19 \\
\hline Construction & 9,02 & 6,56 & 6,11 & 6,97 & 6,36 & 5,22 & 6,26 & 10,38 \\
\hline Mining and Quarrying & 4,29 & 3,02 & 2,53 & 0,43 & $-3,42$ & 1,06 & $-0,49$ & 7,20 \\
\hline Transportation and warehousing & 8,31 & 7,11 & 6,97 & 7,36 & 6,68 & 7,74 & 7,65 & 5,22 \\
\hline Finance and insurance & 6,97 & 9,54 & 8,76 & 4,68 & 8,59 & 8,90 & 5,73 & 4,20 \\
\hline Public adm, defense, and compulsory social security & 6,43 & 2,13 & 2,56 & 2,38 & 4,63 & 3,19 & 0,58 & 3,86 \\
\hline Information and communication & 10,02 & 12,28 & 10,39 & 10,12 & 9,69 & 8,87 & 9,10 & 3,62 \\
\hline Education & 6,68 & 8,22 & 7,44 & 5,47 & 7,33 & 3,84 & 4,11 & 3,37 \\
\hline Accommodation, food and beverages & 6,86 & 6,64 & 6,80 & 5,77 & 4,31 & 4,94 & 4,68 & 2,92 \\
\hline Real estate & 7,68 & 7,41 & 6,54 & 5,00 & 4,11 & 4,30 & 3,67 & 2,81 \\
\hline Other services & 8,22 & 5,76 & 6,40 & 8,93 & 8,08 & 7,80 & 8,01 & 1,71 \\
\hline Business services & 9,24 & 7,44 & 7,91 & 9,81 & 7,69 & 7,36 & 6,80 & 1,70 \\
\hline Electricity and gas & 5,69 & 10,06 & 5,23 & 5,90 & 0,90 & 5,39 & 1,60 & 1,15 \\
\hline Health and sosial activities & 9,00 & 7,96 & 7,96 & 7,96 & 6,68 & 5,00 & 7,13 & 1,07 \\
\hline Water, Waste management, cesspit, and recycling & 4,73 & 3,34 & 3,32 & 5,90 & 0,90 & 5,39 & 1,60 & 0,07 \\
\hline Gross Domestic Product & 6,17 & 6,03 & 5,56 & 5,01 & 4,88 & 5,02 & 5,01 & 100,00 \\
\hline
\end{tabular}

Source: Central Bureau of Statistics, 2017. 
Table 1 exhibits the current condition of the manufacturing industry in Indonesia which is continuously decreasing. the role of the manufacturing industry in GDP remains the highest, at $20.5 \%$ in 2016 . Unfortunately, the trend in the manufacturing sector continues to decline from $6.26 \%$ in 2011 and in 2017 to $4.21 \%$. Currently, the government is accelerating economic growth by boosting the manufacturing sector. The acceleration of growth in the manufacturing sector is expected to increase GDP if the manufacturing industry experiences a $1 \%$ increase alone can increase $0.2 \%$ economic growth.

The development of manufacturing industry in a country can be a parameter of national industrial development. According to Heizer, et. al (2005) manufacturing industry is a group of similar companies that process materials into semi-finished goods or finished goods with greater added value. The Indonesian Cement Association (ASI) statistics data of 2016 cement consumption growth in Indonesia shows a positive trend of increase, the annual average reached $8.4 \%$ in $2010-2015$ period. But that figure is still below the national cement production capacity. The Indonesian Cement Association (ASI) expects a $5 \%$ growth in cement sales in Indonesia which is expected to stimulate investor interest in investing in the cement industry. Increasing sales of the manufacturing industry is not enough to stimulate investor interest, managers recognize that financial statements are parameters used to measure earnings management performance. Earnings information is an important component of financial statements aimed at assessing management performance, as has been recognized that industry manufacturing in its activities rely on capital from investors. This can also trigger the interest of investors to provide or withdraw investment from a company.

Earnings information is a component of a company's financial statements aimed at assessing management performance, forecasting earnings, and estimating risks in investing. Earnings information has an enormous effect on the users in making a decision, so the attention of investors is often focused on earnings information. As already mentioned in the Statement of Financial Accounting Concepts (SFAC) No. 1 that earnings information is generally a major concern in assessing performance or accountability of management and earnings information to help the owner or other party conduct an assessment of future earnings of the company. Under these conditions, management tends to perform an undue behavior in order to make good financial statements. This behavior is usually done by conducting income smoothing that aims to overcome the various interest conflict that arises between management with various parties of interest from the company. The act of smoothing can be defined as the process of profit manipulation, earnings time or earnings reporting to report fewer earnings flow.

Widaryanti (2009) research result stated that firm size, profitability, financial leverage, net profit margin, and variance of company stock value do not affect the practice of income smoothing in manufacturing companies. Another study that examines the factors affecting income smoothing is Pramono (2013), research result exhibits that the debt to equity ratio has no effect on the practice of income smoothing while return on assets, net profit margin, firm size affects income smoothing.

Another factor capable to affect profitability is stock price and earnings per share. Fachrorozi, et. al (2017) conclude a company's stock price has the positive and significant effect on income smoothing while earning per share variable have the negative and significant effect on income smoothing. Based Rahmat's research (2016) on various industry companies listed on Indonesia Stock Exchange, it can be concluded that managerial ownership, return on asset, and economic growth has a positive effect on income smoothing, but price earning ratio has no effect on income smoothing. Price-earnings ratio is not expected to be influential as investors in Indonesia observe capital gains rather than priceearnings ratio. Some of the above research results possess inconsistent results on income smoothing and need to be re-examined. The researcher will develop research model by studying variable stock price, debt to equity ratio, return on asset, earnings per share, price earning ratio and firm size. The purpose of this research is to know the direct influence between variable stock price, debt to equity ratio, return on asset, earnings per share, price earning ratio and firm size to income smoothing in the manufacturing industry. 


\section{LITERATURE REVIEW}

Income Smoothing. According to Koch (1981), income smoothing is defined as the means used by management to reduce reported earnings fluctuations to fit desired targets artificially through accounting methods, as well as in real terms through transactions. According to Ronen and Sadan (1989) and Barnea in Belkoui (1993) income smoothing could be conducted in three ways:

- Management may set a time of occurrence of certain events to reduce reported earnings difference.

- Management may allocate certain revenues and expenses in different accounting periods.

- Management at the discretion of classifying specific profit items into different categories.

Foster (1986) states the purpose of income smoothing is to (1) Improve the image of the company in the eyes of outsiders, that the company has a low risk; (2) Provide relevant information in predicting future earnings; (3) Improving business relationship satisfaction; (4) Improving external party perceptions of management capabilities; (5) Increase compensation for management.

Stock Price. Brigham and Houston (2010) defined stock price as determinants of shareholder wealth. Maximizing shareholder wealth translates into maximizing the company's stock price. The stock price at one particular time will depend on the cash flow expected to be received in the future by the "average" investor if the investor buys the stock. According to Sartono (2015) "Stock market prices are formed through the mechanism of demand and supply in the capital market.

Debt to Equity Ratio. Cashmere (2014) states that "Debt to Equity is a ratio used to assess debt and equity. This ratio is sought by comparing the entire current debt with all equity debt ". Meanwhile, according to Syafri (2010) "This ratio describes the extent to which the owner's capital can cover the debts to outsiders, The smaller the ratio the better. This ratio is also called leverage ratio. For outsider security, the best ratio is when the capital is greater than the amount of debt or at the same amount. Nevertheless, leverage ratio should be large for shareholders or management". Based on the two expert opinions, it can be concluded that the Debt to Equity Ratio is the ratio used to calculate debt and capital, which can cover the debts to outsiders. Debt to equity ratio in each company is different, depending on business characteristics and diversity of cash flow. Firms with stable cash flow typically have higher ratios than less stable cash ratios.

Return On Asset. According to Riyanto (1999), Return On Asset is a ratio that shows the company's ability to generate a net profit for all investors of the capital invested in the overall assets. The higher the Return On Asset the higher the company's ability to generate profits. Analysis of Return On Assets in the financial analysis has a very important meaning as a comprehensive financial analysis technique. Return On Assets (ROA) itself is one form of profitability ratio that is intended to measure the ability of the company with the overall funds invested in the assets used for the company's operations to generate profits. Thus Return On Assets connects the profits derived from the operating company (Net Operating Income) with the amount of investment or assets used to generate operating profit (Net Operating Assets).

Earning Per Share. Earnings per share are the ratio that shows the income earned per share (Gibson, 1996). Meanwhile, according to Weygandt et. (1996) earnings per share assesses the net income earned per share of common stock. One reason investors buy stocks is to get dividends if the value of earnings per share is small, the possibility of companies to distribute dividends is small as well. Therefore investors will be more interested in stocks possessing high earnings per share than stocks that have low earnings per share. Low Earnings per Share tends to keep stock prices down.

Price Earning Ratio. Garrison and Noreen (2000) stated that the Price Earning Ratio reflects the relationship between stock market prices and current EPS widely used by investors as a general guide to measuring stock values. Price Earning Ratio is used by 
investors to predict the company's ability to generate future profits. Investors can consider this ratio to sort out which stocks will benefit substantially in the future. Price Earning Ratio shows the relationship between the market price of common stock and earnings per share. Companies with a high growth rate opportunity usually have a high PER, and companies with low growth have a small or low PER. PER has no meaning if the company has very low (abnormal) or negative profits.

Firm Size. Machfoedz (1994) defined firm size as a scale which classifies a company's size in various ways, including total assets, log size, stock market value, etc.. The size of the company is only divided into 3 categories: large, medium and small companies. The determination of the size of the company is based on the total assets of the company. Moses's (1997) study proves that larger firms have a greater incentive to conduct income smoothing than smaller firms because larger firms are subject to scrutiny (closer scrutiny from governments and the general public). Albretch and Richardson (1990) research found that larger firms have a drive conduct income smoothing compared to smaller firms because larger firms are studied and viewed more critically by investors.

\section{METHODS OF RESEARCH}

The type of data used in this study is secondary data 2013 to 2017 obtained from www.finance.yahoo.com and www.idx.co.id The research population is companies that are in the manufacturing industry, basic industry and chemical sector, cement sub-sector listed on $\mathrm{BEI}$. The sample used is based on the criteria of the company whose shares are always registered and active in IDX trading minimum since 2005 and always present the financial information during the observation period. Based on the criteria, the companies that are being sampled are Indocement Tunggal Perkasa Tbk, Holcim Indonesia Tbk, Cement Indonesia (Persero) Tbk. Data analysis method used is multiple linear regression models as follow:

$$
Y=\alpha+\beta_{1} X_{1}+\beta_{2} X_{2}+\beta_{3} X_{3}+\beta_{4} X_{4}+\beta_{5} X_{5}+\beta_{6} X_{6}
$$

Where: $Y=$ Income Smoothing; $\alpha=$ Constant; $\beta_{1} \beta_{6}=$ Coefficient of Regression; $X_{1}=$ Stock Price; $X_{2}=$ Debt to Equity Ratio; $X_{3}=$ Return on Asset; $X_{4}=$ Earning Per; $X_{5}=$ Price Earning; $X_{6}=$ Firm Size.

The simultaneous influence of exogenous variables on endogenous variables can be determined to explore the significance test $F$, with the following hypothesis:

- Ho = exogenous variables have no significant effect on endogenous variables;

- $\mathrm{Ha}=$ exogenous variable has a significant effect on endogenous variable.

Terms accepted or Ho accepted hypothesis proposed simultaneously if the value of Sig $\mathrm{F}>\alpha 0.05$ and if the value of Sig $\mathrm{F}<\alpha 0.05$ then Ha accepted.

To determine partially the effect of exogenous variables on endogen, researchers used $\mathrm{t}$ significance test with the following hypothesis:

- Ho = exogenous variable $\left(X_{i}\right)$ has no significant effect on endogenous variables;

- $\mathrm{Ha}=$ exogenous variable $\left(X_{i}\right)$ have a significant effect on endogenous variables.

Terms accepted or Ho accepted hypothesis proposed simultaneously if the value of Sig $\mathrm{t}>\alpha 0.05$ and if the value of Sig $\mathrm{t}<\alpha 0.05$ then Ha accepted.

The beta regression coefficient test is conducted by determining standardized coefficients beta obtained from multiple regression analysis using SPSS version 22 software. This test is conducted to determine which exogenous variables have a dominant influence on endogenous variables. To ensure that the obtained model actually meets the best linear unbiased estimator (BLUE) principle, the researchers used the basic assumption test and the classical assumption test. Test of basic assumption in this research utilized normality test. As for the classical assumption test used multicollinearity test and autocorrelation test. 


\section{RESULTS OF STUDY}

Examination result on the basic assumptions and classical assumptions. The first assumption test is the normality test, where the test is performed by determining the Kolmogorov-Smirnov value, where the results of the data have a normal distribution because the Kolmogorov-Smirnov value has a significance level of $0.325<0.05$.

Table 2 - Results of Kolmogorov Smirnov Test

\begin{tabular}{ll}
\hline Kolmogorov Smirnov Z & .303 \\
\hline Asymp. Sig (2-tailed) & .325 \\
\hline
\end{tabular}

Source: reprocessed, 2018.

The next stage is the Multicollinearity Test. A model is said to not occur multicollinearity, if the value of variance inflation factor (VIF) $<10$ (Ghozali, 2016). Table 3 exhibits that Multicollinearity does not occur between independent variables because of the VIF value of each variable $<10$.

Table 3 - Multicollinearity Test Results

\begin{tabular}{lll}
\hline \multirow{2}{*}{ Model } & Collinearity Statistics & \\
\cline { 2 - 3 } & Tolerance & VIF \\
\hline Stock Price & .802 & 1.247 \\
\hline Dept to Equity Ratio & .709 & 1.410 \\
\hline Return on Asset & .831 & 1.203 \\
\hline Earning Per Share & .851 & 1.175 \\
\hline Price Earning Ratio & .797 & 1.255 \\
\hline Firm Size & .962 & 1.039 \\
\hline
\end{tabular}

Source: reprocessed, 2018.

The last test to fulfill the principle of best linear unbiased estimator (BLUE) is an autocorrelation test. A model can be declared no symptoms of autocorrelation if the Durbin Watson value> 0.05 (Ghozali $(2016 ; 107)$ ). Table 4 exhibits the Durbin Watson value at $1.936>0.05$, it can be said that the model has no autocorrelation.

Table 4 - Multicollinearity Test Results

\begin{tabular}{ll}
\hline Durbin Watson & Description \\
\hline 1,936 & No Autocorrelation occurrence \\
\hline
\end{tabular}

Source: reprocessed, 2018.

Results obtained from software SPSS Ver.22 to determine the value used as a proof of hypothesis is presented in table 5 below:

Table 5 - Recapitulation of Results of Multiple Linear Regression

\begin{tabular}{|c|c|c|c|c|}
\hline Formula & Coefficient of Regression & T-test (Sig) & Coefficient of Determination & F Test (Sig) \\
\hline \multirow{7}{*}{ Income Smoothing } & $\alpha=1.315$ & $1.207(0.230)$ & \multirow{7}{*}{ 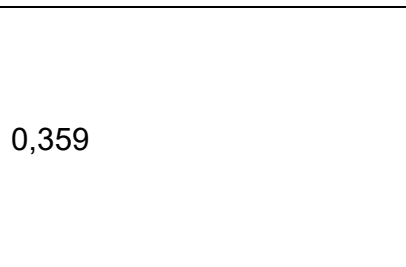 } & \multirow{7}{*}{$9.439(0.000)$} \\
\hline & $\beta 1=0.350$ & $3.778(0.007)$ & & \\
\hline & $\beta 2=0.060$ & $2.384(0.009)$ & & \\
\hline & $\beta 3=0.010$ & $0.666(0.507)$ & & \\
\hline & $\beta 4=-0.089$ & $-2.282(0.006)$ & & \\
\hline & $\beta 5=0.075$ & $2.225(0.008)$ & & \\
\hline & $\beta 6=-0.005$ & $-0.046(0.964)$ & & \\
\hline
\end{tabular}

Source: Reprocessed, 2018.

The results are presented in table 5, it obtained multiple linear regression equations as follows: 


$$
Y=1.315+0.350 X_{1}+0.060 X_{2}+0.010 X_{3}-0.089 X_{4}+0.075 X_{5}-0.046 X_{6}
$$

The test column $\mathrm{F}$ in table 5 , exhibits sig value for regression testing 0.000 . This value is smaller than 0.05 or sig $<\alpha$ value. This indicates the hypothesis stating "exogenous variable significant effect on the endogenous variable" accepted. Furthermore, column T test exhibits sig value for each variable. Only return on asset and firm size that has value> 0.05 at 0.507 and 0.964 respectively. This means the hypothesis stating "variable return on asset and firm size no effect significant to income smoothing "is accepted. While the other variables are stock price, debt to equity ratio, earnings per and price earning respectively have value $0.007,0.009,0.006$ and 0.008 , this means the hypothesis which states "variable stock price, debt to equity ratio, earnings per and price earnings significant effect on income smoothing "is accepted.

Table 5 also exhibited coefficient of determination value equal to 0.359 . This means that stock price, debt to equity ratio, return on asset, earnings per share, price earnings ratio, and firm size variables contribute to income smoothing value equal to $35.9 \%$ while the rest of $64.1 \%$ is explained by other variables not included in this research model.

\section{DISCUSSION OF RESULTS}

Based on the research result, empirical evidence found a tendency of companies listed on the Jakarta Stock Exchange to conduct income smoothing. This was proposed by Setyaningsih and Marisan (2010). In accordance with research result, only return on asset and firm size possess no significant effect on income smoothing. ROA variable does not affect the income smoothing to support the research result conducted by Jin and Machfoedz (1998), Salno and Baridwan (2000), and Juniarti and Corolina (2005). Most research conducted in Indonesia on factors affecting earnings smoothing practices does not succeed in supporting that profitability (ROA) has a significant effect on the practice of income smoothing.

Furthermore, a firm size that has no effect and not significant to income smoothing. It can be said that firm size is not a variable that affects income smoothing in the manufacturing industry. This result indicates that while observing a relatively optimal position of corporate assets, it also makes it difficult for managers to use assets as a means of income smoothing. This research result is similar to Jin and Machfoedz (1998), Jatiningrum (2000), Juniarti Carolina (2005), and Dewi and Carina (2008). However, unlike the Budiasih (2009) research result, it shows that firm size variable significantly affect income smoothing.

\section{CONCLUSION}

It is estimated that there are manufacturing companies listed on the Indonesia Stock Exchange to practice income smoothing. The income profit practices undertaken by a manufacturing company will mislead investors in analyzing financial statements as a basis for making investment decisions as well as for creditors in long-term loan decisions. Stock price, dept to equity ratio, earnings per share and price earning ratio partially possess influence to income smoothing. Return on asset and firm size is not significant to income smoothing. All variables studied have the influence to income smoothing.

\section{LIMITATION AND FUTURE STUDY}

Limitations that exist in this study in determining the effect of income smoothing merely through analyzing six factors. The six factors are stock price, debt to equity ratio, return on asset, earnings per share, price earning ratio and firm size. There are many other factors that can influence income smoothing. In this research manufacturing companies in the basic and chemical industry sector and cement sub-sector listed in BEI does not include all companies engaged in the manufacturing industry. 
This research can be developed more broadly by paying more attention to return on asset and firm size. These factors can be developed because in this study these factors do not significantly affect income smoothing. The company engaged in the manufacturing industry and listed on the stock exchange of Indonesia could be used as a sample of research. Therefore it can represent the income smoothing occurred in Indonesian manufacturing industry.

\section{REFERENCES}

1. Albrecht, W. D. and Richardson, F. M., 1990.“IncomeSmoothing by Economy Sector", Journal of Business Finance\& Accounting, Vol. 17 (5), pp. 713- 730.

2. Badan Pusat Statistik Jakarta Pusat , 2017. Statistik Indonesia Tahun 2017. Jakarta Pusat: Badan Pusat Statistik.

3. Barnea, A., Ronen, J., and Sadan, S. (1989). Classificatory Smoothing of Income with Extraordinary Items, Behavioral Accounting. Greenword Press. Westport, CT.

4. Belkaoui, Ahmed. 1993, Accounting Theory, ed. Ke-2, Harcourt Brace Jovanovich, Inc., Terjemahan. Jakarta: Erlangga.

5. Brigham F. Eugene dan Houston, Joel. (2010). Dasar - Dasar Manajemen Keuangan: Assetials Of Financial Management. Jakarta: Penerbit Salemba Empat.

6. Budiasih, Igan. 2009. Faktor-Faktor yang Mempengaruhi Praktik Perataan Laba. Jurnal Akuntansi Bisnis, Vol. 4 No. 1, pp. 44-50.

7. Dewi, Sofia Prima dan Carina. 2008. Faktor-Faktor yang Mempengaruhi Praktik Perataan Laba pada Perusahaan Manufaktur dan Lembaga Keuangan Lainnya yang Terdaftar di Bursa Efek Jakarta. Jurnal Akuntansi Tahun XII, No. 02, May 2008, pp. 117-131

8. Fachrorozi. Sinarwati, Ni Kadek Sinarwati. Purnamawati, I Gusti Ayu. Pengaruh Cash Holding, Harga Saham Perusahaan, dan Earning Per Share Terhadap Income Smoothing (Studi Empiris Perusahaan Manufaktur Yang Terdaftar Di Bursa Efek Indonesia). e-Journal S1 Ak Universitas Pendidikan Ganesha, Volume: 7 No:1).

9. Financial Accounting Standards Board (FASB) dalam Statement of Financial Concept (SFAC) No. 1.

10. Foster. 1986. "Financial Statement Analysis" Englewood, New Jersey, Prentice Hall International, 1986.

11. Garrison. R. H. \& E. W. Noreen. (2000). Managerial Accounting (ninth edition). The McGraw-Hill Companies, Inc

12. Ghazali, Imam. (2016). Aplikasi Analisi Dengan Program Spss IBM Spss 23. Semarang: Badan Penerbit Universitas Diponegoro.

13. Gibson, JL, et al. (1996). Organisasi, Perilaku, Struktur dan Proses, First Edition, Jakarta: Bina Rupa Aksara.

14. Heizer Jay, Render Barry. 2005. Operations Management. Jakarta: Salemba Empat.

15. Jatiningrum, Analisis Faktor-Faktor yang Berpengaruh Terhadap Perataan Penghasil Bersih/Laba pada Perusahaan Yang Terdaftar di BEJ, Jurnal Bisnis dan Akuntansi, Vol. 2, No. 2, pp.145-155.

16. Jin, Liauw She dan Mas'ud Machfoedz, Faktor-Faktor yang memperngaruhi Praktik Perataan Laba pada Perusahaan yang Terdaftar di Bursa Efek jakarta, Jurnal Riset Akuntansi Indonesia, Vol. 1, No. 2, pp.174-191.

17. Juniarti dan Corolina. 2005. Analisa Faktor-faktor yang Berpengaruh Terhadap Perataan Laba (Income Smoothing) pada Perusahaan Go Public. Jurnal Akuntansi dan Keuangan. Volume 7, No 2.

18. Kasmir. 2010. Analisis Laporan Keuangan. Jakarta: Raja Grafindo Persada

19. Kasmir. 2014. Analisis Laporan Keuangan. Jakarta: PT Raja Grafindo Persada.

20. Koch, Bruce, S., "Income Smoothing An Experiment", The Accounting Review, Vol. LVI, No. 3, pp.574-586.

21. Machfoedz, Mas'ud, "Financial Ratio Analysis and The Prediction of Earnings Changes in Indonesia”, Kelola: Gajah Mada University Business Review, No. 7/III/1994. 
22. Moses, O., D. 1997. "Income Smoothing and Incentives: Empirical Test Using Accounting Changes", The Accounting Review, pp. 358-377.

23. Pramono, Olivya. 2013. Analisis Pengaruh ROA, NPM, DER, dan Size Terhadap Praktik perataan laba (studi kasus pada perusahaan Manufaktur yang terdaftar di bursa efek indonesia Periode 2007-2011). Jurnal IImiah Mahasiswa Universitas Surabaya Vol.2 No.2

24. Pramono, Olivya. 2013. analisis pengaruh roa, $\mathrm{npm}$, der, dan size terhadap praktik perataan laba (studi kasus pada perusahaan manufaktur yang terdaftar di bursa efek indonesia periode 2007-2011). Jurnal Imiah Mahasiswa Universitas Surabaya. Vol 2. No.2

25. Rahmat, Hasfhi. 2016. Pengaruh Kepemilikan Manajerial, Price Earning Ratio, Return on Asset, dan Pertumbuhan Ekonomi Terhadap Income Smoothing (Studi Empiris pada Perusahaan Aneka Industri yang Terdaftar di BEI Tahun 2010-2014). Jurnal Ilmiah Universitas Bakri Vol 4, No 01.

26. Riyanto, Bambang. 1999. Dasar-dasar Pembelanjaan Perusahaan. Yogyakarta. BPFE.

27. Salno, Hanna Meilani., \& Baridwan, Zaki. 2010. Analisis PErataan Pengahasilan (Income Smoothing): Faktor-faktor yang mempengaruhi dan kaitannya dengan kinerja saham perusahaan public di Indonesia. The Indonesian Journal of Accounting Research. Vol 3 No.1.

28. Sartono, Agus. 2015. Manajemen Keuangan: Teori dan Aplikasi. BPFE Yogyakarta.

29. Setyaningsih, lis dan Marisan, Ichwan. 2010. Analisis faktor-faktor yang berpengaruh terhadap tindakan perataan laba pada perusahaan manufaktur di BEl. Jurnal Dinamika Ekonomi dan Bisnis. Vol.17 No.1.

30. Sunariyah. 2011. Pengantar Pengetahuan Pasar Modal Edisis Keenam. Yogyakarta: UPP STIM YKPN

31. Syafri, Sofyan. 2010. Analisis Kritis Atas Laporan Keuangan. Edisi Satu. Jakarta: Raja Grafindo Persada

32. United Nations Industrial Development Organization (UNIDO). 2012. Annual Report 2012.

33. Weygandt, et.al. (1996). Accounting Principle. (Penerjemah: Ali Akbar Yulianto,Wasila, Rangga Handika). Jakarta: Salemba Empat.

34. Widaryanti. 2009. Analisis Perataan Laba dan Faktor-Faktor Yang Mempengaruhi Pada Perusahaan Manufaktur di Bursa Efek Indonesia. Jurnal Fokus Ekonomi, Vol.4. No. 2 pp. 60-77.

35. Widaryanti. 2009. Analisis Perataan Laba dan Faktor-Faktor Yang Mempengaruhi Pada Perusahaan Manufaktur di Bursa Efek Indonesia. Jurnal Fokus Ekonomi. Vol.4. No. 2 pp. 60-77. 